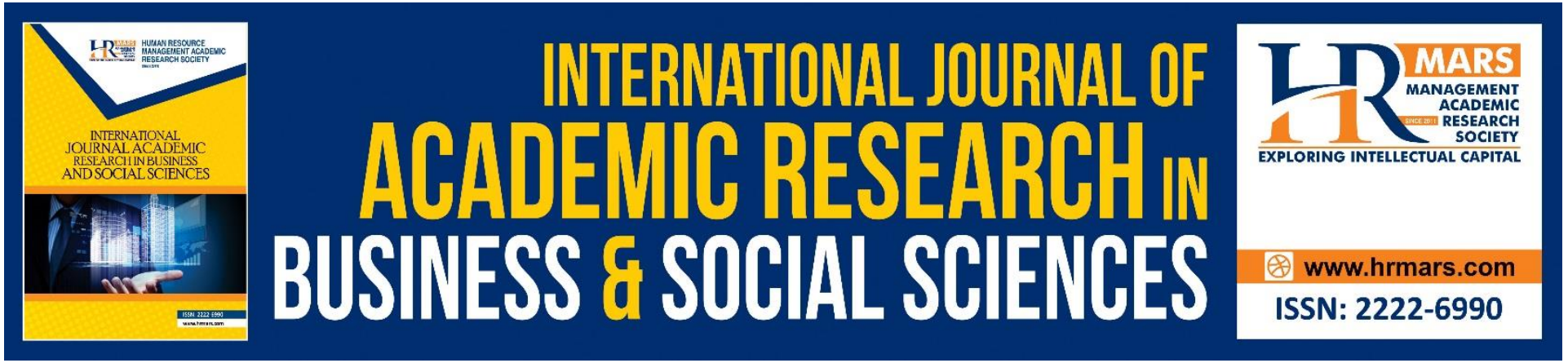

\title{
Community Policing As a Prevention of Street Crime in Kuala Lumpur
}

\section{Mohd Radzi bin Abdul Rahman, Ahmad Zainal Abidin bin Abd Razak}

To Link this Article: http://dx.doi.org/10.6007/IJARBSS/v11-i7/10521

DOI:10.6007/IJARBSS/v11-i7/10521

Received: 10 May 2021, Revised: 15 June 2021, Accepted: 02 July 2021

Published Online: 23 July 2021

In-Text Citation: (Rahman \& Razak, 2021)

To Cite this Article: Rahman, M. R. bin A., \& Razak, A. Z. A. bin A. (2021). Community Policing As a Prevention of Street Crime in Kuala Lumpur. International Journal of Academic Research in Business and Social Sciences, 11(7), 637-644.

\section{Copyright: (c) 2021 The Author(s)}

Published by Human Resource Management Academic Research Society (www.hrmars.com)

This article is published under the Creative Commons Attribution (CC BY 4.0) license. Anyone may reproduce, distribute, translate and create derivative works of this article (for both commercial and non-commercial purposes), subject to full attribution to the original publication and authors. The full terms of this license may be seen at: http://creativecommons.org/licences/by/4.0/legalcode

\section{Vol. 11, No. 7, 2021, Pg. 637 - 644}

Full Terms \& Conditions of access and use can be found at http://hrmars.com/index.php/pages/detail/publication-ethics 


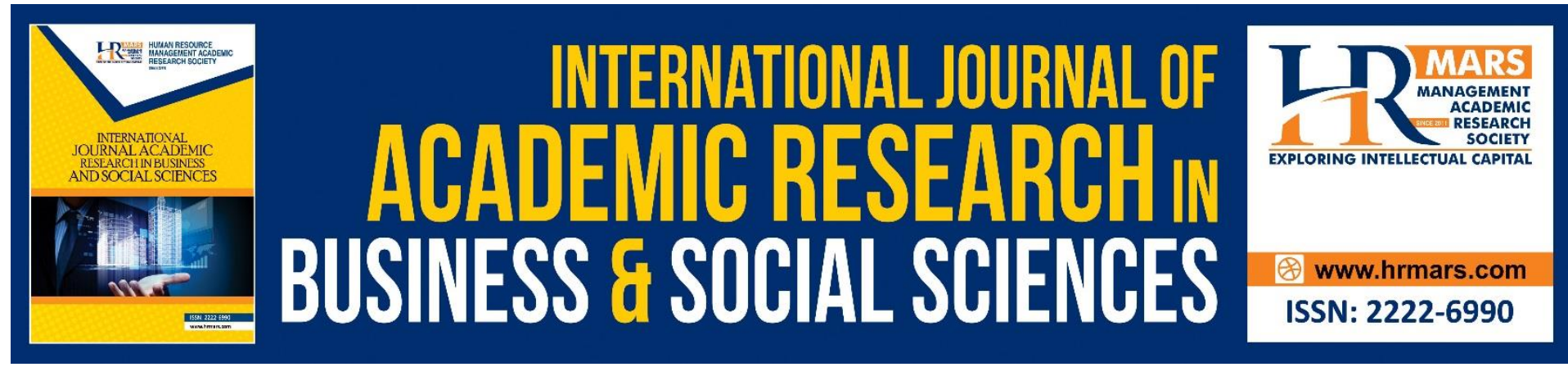

\title{
Community Policing As a Prevention of Street Crime in Kuala Lumpur
}

\author{
Mohd Radzi bin Abdul Rahman, Ahmad Zainal Abidin bin Abd \\ Razak
}

Sultan Idris Education University, Malaysia

\begin{abstract}
Community policing has been introduced by PDRM since 2012 which brings the police closer to the community or in other words 'public involvement'. In Malaysia, based on community policing, the community needs a police organization. The concept of community police crime prevention has long been specially developed for street crime prevention in Kuala Lumpur. This study was conducted to explore the effectiveness of community policing distance in Kuala Lumpur in the effort to prevent street crime in the occurrence of index crime cases. Findings from this study to further increase the effectiveness of this police distance in addition to appropriate joint ventures carried out between communities at various levels with the police in the fight against street crime.
\end{abstract}

Keywords: Crime Prevention, Community Policing, Community, Crime, Crime Index

\section{Introduction}

Crime has an impact in the social, economic, health, and psychological contexts of victims and society in general. It is a serious social problem that directly reduces the quality of life of individuals and society (Moffitt, 2017). To overcome this problem, a police department was set up in the care and safety of the public. In support of this idea, (Silver, 2017) states, "the main function of the police is to prevent crime and arrest criminals". usually the exclusive role of the police as the main agent of law enforcement in the absence of widespread active participation of members of the community together in combating crime. At that time, the police not only faced difficulties in dealing with crime but also faced unfriendly nature in the context of community relations. For example, Becker stated that the police would not be successful in solving or preventing crime without the help of the community. Therefore, to achieve success in combating crime, there must be sharing and involvement from the community. Therefore, in response to this development, the concept of community-oriented policing was introduced (Becker, 2017).

community policing is a paradigm shift established on the basis of sharing with the community in creating a safe environment for all. It is a form of policing in which communities actively participate in their own affairs; The police are not seen as a problem or an enemy whose presence poses a danger but the police are part of the community (Nitsch \& Ronert, 2017). One rational reason for the need for community involvement in preventing crime is that the 
police alone cannot create or maintain a safe community, so the concept of community policing has emerged as a major issue in the development of public safety for most countries. Community policing is considered to be a very effective method of preventing crime and improving community security, but so far as it is able to be a more responsible, responsive or democratic form of policing as the community is responsible, it becomes a question. Around the world, community policing has emerged in many areas that have been the product of their physical environment and culture. Through a series of case studies, community policing within community customs explains how often divided communities operate under the community policing paradigm. Although 'fear of crime or fear of becoming a victim of crime' has generated significant academic interest, the lack of explanation on definition, prevalence and focus has created difficulties for enforcers to practice community policing systems when implementing operational initiatives (Cross, 2015). The main goal of the police is to protect the community against violations of the law and to threaten the peace which is necessary to ensure the safety of every citizen. In this case public appraisal is considered one of its main criteria. The level of public confidence in the police will identify the effectiveness of its work. Police and community need to adapt to changing interactions and improve communication in an effort to increase cooperation in ensuring community safety (Pridmore et al., 2019).

The concept of community-oriented policing has emerged in Malaysia since 2014 as an important strategy to control and prevent crime, as well as improve community security. In addition, the concept of policing is expected to be able to reduce anxiety and provide awareness to the community about crime. This concept has been approved in three phases. The first phase only involves the police contingent of Kuala Lumpur, Selangor, Penang and Johor, while the second phase involves each police contingent at the state level in Malaysia, and finally, followed by the third phase involving each police contingent in each region in each state in Malaysia.

\section{Study Background}

Rapid modernization and industrialization have led to structural changes not only in economic and political aspects but also in social aspects. In addition, changes in lifestyle have increased one's awareness of security, individual rights, and even awareness of the collective power that has begun to change the social aspects of human beings. In fact, safety has become a factor, and it is basically necessary to achieve a better quality of life. In addition, the public is now paying more attention to achieve a better level of security especially in urban areas. In relation to the issue of crime and security, Malaysia has adopted a police method similar to the British Neighborhood Police Force (NPT) known as the community-oriented police (COP) in Malaysia. Community-oriented police have been introduced to create a safer living environment. The concept of community-oriented policing (COP) is implemented based on a partnership between the police department and the community where both parties will share the responsibility to identify, reduce, eliminate and prevent problems related to community safety and order. The Malaysian government has tried to allocate more resources towards combating crime and set up more agencies to review police books and actions, as well as investigate public complaints. The Royal Malaysian Police (PDRM), has introduced community-oriented policing into the Malaysian police strategy. The concept of communityoriented policing has emerged in Malaysia since 2012 as an important strategy to control and prevent crime, as well as improve community security. 
Kuala Lumpur is one of the earliest contingents to implement community-oriented policing in an effort to tackle and reduce crime. The main contributor to crime in Kuala Lumpur is cases involving street crime. Based on the statistics of street crime in each state in Malaysia from 2016 to 2018, in 2014, 2015 and 2016, Kuala Lumpur is the highest area to record street crime cases. Meanwhile, in 2017 and 2018, Kuala Lumpur showed a significant decrease in cases and was not in the top position in street crime case statistics in Malaysia (Table 1). However, no empirical study was conducted to explore the effectiveness of community-oriented police implementation because from 20142016 Kuala Lumpur still recorded the highest number of street crime cases despite having implemented it, and despite showing a decrease in cases in 2017 and 2018, there is no evidence that it happened due to the implementation of this police approach. Scientific research needs to be done to explore the effectiveness of this community-oriented police philosophical approach, really helping the PDRM in Kuala Lumpur in efforts to reduce street crime cases.

Apart from that, the approach of community policing implementation in each district within the Kuala Lumpur contingent varies despite having the same goal which is in efforts to reduce street crime cases. There is no uniform form of procedure manual that can be applied by every district in the Kuala Lumpur contingent. Therefore, this study needs to be done in an effort to explore the effectiveness of this police philosophy, and then develop a uniform implementation manual in an effort to eradicate street crime cases in Kuala Lumpur.

In conclusion, based on the factors presented by the researchers, it is very necessary to conduct an empirical study to explore the implementation of community policing by the authorities in Kuala Lumpur in the fight against street crime. Furthermore, the information obtained in the study conducted helps in efforts to improve the implementation of this police concept in addition to being able to create the implementation of this police concept uniformly throughout the district in Kuala Lumpur.

Table 1. Street crime statistics of each state in Malaysia

\begin{tabular}{|c|c|c|c|c|c|}
\hline NEGERI & 2014 & 2015 & 2016 & 2017 & 2018 \\
\hline Johor & 6,501 & 3,445 & 2,964 & 2,452 & 2,053 \\
\hline Kedah & 1,395 & 1,134 & 1,042 & 973 & 878 \\
\hline Kelantan & 565 & 428 & 412 & 327 & 253 \\
\hline Kuala Lumpur & $\mathbf{1 0 , 4 3 9}$ & $\mathbf{6 , 7 6 1}$ & $\mathbf{6 7 2 9}$ & $\mathbf{5 , 7 2 0}$ & $\mathbf{5 6 1 0}$ \\
\hline Melaka & 561 & 459 & 469 & 495 & 512 \\
\hline $\begin{array}{c}\text { Negeri } \\
\text { Sembilan }\end{array}$ & 1,376 & 1,076 & 1,161 & 1,173 & 862 \\
\hline Pahang & 481 & 307 & 301 & 420 & 384 \\
\hline Perak & 1,954 & 1,580 & 1,445 & 1,338 & 1,145 \\
\hline Perlis & 21 & 81 & 72 & 68 & 50 \\
\hline Pulau Pinang & 2,526 & 1,847 & 1,062 & 1,035 & 1,064 \\
\hline Sabah & 871 & 649 & 500 & 453 & 417 \\
\hline Sarawak & 1,206 & 946 & 756 & 600 & 548 \\
\hline Selangor & 10,170 & 6,653 & 6,579 & 7,238 & 7,945 \\
\hline Terengganu & 257 & 227 & 245 & 221 & 192 \\
\hline Total & $\mathbf{3 8 , 3 2 3}$ & $\mathbf{2 5 , 5 9 3}$ & $\mathbf{2 3 , 4 0 8}$ & $\mathbf{2 2 , 5 1 3}$ & $\mathbf{2 2 , 3 3 0}$ \\
\hline
\end{tabular}

(Source: Royal Malaysia Police 2019) 


\section{Statement of Study Problems}

Crime not only affects individuals, but also affects communities and cities. Street crime is a major issue in Malaysia, especially in urban areas. Four states including Kuala Lumpur, Johor, Selangor and Penang are the states that recorded a high number of street crime cases which accounted for about $70 \%$ of street crime statistics reported annually. Nearly half $(49 \%)$ of Malaysians feel insecure and afraid of becoming victims of crime. In addition, feeling insecure and worried about the situation has caused people to be cautious in carrying out their daily activities (Ghani, 2017). The community-oriented police (COP) approach began to be implemented in Malaysia.

Recognizing the importance of ensuring the economic development and quality of life of Malaysians, government involvement through the Ministry of Home Affairs (KDN) makes crime reduction one of the six National Key Result Areas (NKRAs) introduced, whose main goal is to continuously reduce the reported crime index., with a focus on street crimes namely, robbery without firearms, robbery of friends without guns and snatching. Thus, the issue of street crime in Malaysia has received quite serious attention from the government. The government has openly stated its target to reduce the street crime index in Malaysia. Therefore, the strong commitment and cooperation from all parties, especially the Ministry of Home Affairs (KDN), the authorities and non-governmental organizations (NGOs) bring efforts to reduce the street crime index. However, PDRM faces challenges to realize the government's aspirations in terms of lack of personal numbers. The number of police personnel in Malaysia is around 111,500 to maintain the security of the whole country which consists of 32 million people, this ratio clearly shows that Malaysia lacks PDRM membership, the ideal ratio at the international level is 1: 250 (Rasdi, Irniza \& Saliluddin, 2018). So it is clearly not practical for PDRM to implement it. Therefore, a new approach to policing has been implemented to achieve this goal, among the approaches used is the community policing approach which has the concept of joint problem solving between the police and the community in dealing with criminal phenomena.

The concept of community policing was first introduced in the United States in the 1960s, which is a policing strategy that focuses on enhancing cooperation between the police and community members in crime prevention efforts. Community policing is a specialized police service philosophy, in which the same officers conduct patrols and monitoring in the same area on a regular basis, from decentralized places, working in proactive partnerships with the community to identify and solve problems (Makin \& Marenin, 2017). The concept of community-oriented policing has emerged in Malaysia since 2012, where Kuala Lumpur is one of the earliest contingents to implement a community policing approach. Although the implementation of community policing has been implemented specially to deal with street crime, Kuala Lumpur still recorded the highest number of street crimes for 2014, 2015, and 2016, and showed a decrease in 2017 to 2018 (Bukit Aman Criminal Investigation Department, 2019). This information shows that in 2017 to 2018 Kuala Lumpur still recorded the highest number of cases, and shows the decrease in cases for 2017 to 2018 is the effect of the implementation of this police philosophy, clearly an empirical study to explore the effectiveness of community policing implementation. Based on some empirical evidence of research studies related to the concept of community policing implemented in several countries such as (Leventakis, Kokkinis, \& Papalexandratos, 2017) United Kingdom, (Rukus, Warner, Me \& Zhang, 2018) United States, (Hunting, \& Helbich, 2017) South Africa, and 
(Crowl, 2017) Singapore show the role, effectiveness, implementation challenges, and outcomes of community policing implementation vary for each country. In addition, (Ibrahim, Saleh, \& Mukhtar, 2016) stated that community policing is a relatively new practice in law enforcement which involves the cost and involvement of the community in various programs implemented which- the difference depends on the police department. However, there is limited data that determines whether community policing practices are valuable for use by police departments in other areas. The challenges, principles and benefits of community policing vary from place to place.

In conclusion, based on the information gap presented, the purpose of the current study is to explore the effectiveness, challenges, and practice of community policing in Kuala Lumpur in an effort to prevent street crime. Although almost a decade of community policing has been implemented but no scientific research has been done to explore the implementation of community policing as a street crime prevention strategy implemented in Kuala Lumpur, clearly shows an empirical study needs to be conducted by researchers to explore the implementation of this policing approach.

\section{Research Objective}

The main objective of this research study is to explore the extent to which communityoriented police (COP) implementation strategies are useful in efforts to prevent crime, especially street crime in Kuala Lumpur. In addition, the purpose of the research is to understand the type of relationship that exists between the police and other stakeholders in the prevention of street crime in Kuala Lumpur. This main goal then leads to 4 specific objectives, namely:

a) Identify the current relationship between the police and the community in the prevention of street crime through the implementation of community-oriented policing (COP) in Kuala Lumpur.

b) Explore the effectiveness of the implementation of community-oriented policing in the prevention of street crime in Kuala Lumpur.

c) Obtain views from various levels of the community to improve the community policing approach for the prevention of street crime in Kuala Lumpur.

d) Develop guidelines for appropriate forms of cooperation between the Police and the Kuala Lumpur community in the implementation of community-oriented police (COP) strategies to prevent street crime.

\section{Importance of the Study}

Community-oriented police have emerged in Malaysia since 2012 as an increasingly important strategy to control and prevent crime, as well as improve community security. The four important reasons to study community policing on crime prevention are: -

The empirical findings in this study provide a new understanding of the comparison of conventional policing methods where the role and responsibility of combating crime lies entirely on the shoulders of law enforcement with a more contemporary method towards modern policing i.e. collaborative cooperation between law enforcement and society. Conventional policing methods have weaknesses in terms of collaborative interaction between law enforcement and society, the emphasis of modern policing that is community- 
oriented in crime prevention is seen to have more strength, including reducing fear of crime among society and giving public awareness of crime.

The main priorities of modern policing are community oriented and crime prevention. To achieve this goal, in part, by developing a more dynamic relationship between society and law enforcement agencies. Thus the involvement of the community in joint efforts to solve or to prevent crime with the police indirectly helps the police for enforcement activities.

Community-oriented police provide a hint of cooperation between the community and the authorities. This shows more understanding and enforcement of component laws dedicated to working collaboratively to solve community problems especially crime problems. Indirectly, complaints against the police about crime can be reduced, especially street crime, if the community appreciates the benefits of community policing programs. Creating a more integrated community, where together involved in crime prevention in a productive way with the police to ensure they are safer.

Therefore, the practice of community-oriented policing (COP) is widely considered as one of the developments in the philosophy of policing today, more importantly it is a method in effective crime prevention strategies around the world. This concept has been widely discussed and applied in various countries and in various contexts, thus studying the effectiveness and challenges of community-oriented policing can contribute in providing experience and viable direction in combating crime through community-oriented policing, understanding community challenges directly related to efforts to reduce crime in Malaysia in general and in the study area of Kuala Lumpur in particular.

\section{Limitations of the Study}

This research is only focused on the administrative area of a government enforcement agency in Kuala Lumpur. The results of the study depend on the honesty of the respondents in answering each question posed by the researcher. This study only focuses on street crime and does not cover all types of crimes that occur.

\section{Summary}

This chapter introduces issues related to the topic being explored and explains the basic ideas of the research. Further, this chapter briefly describes the circumstances that warrant research on the implementation of community-oriented policing (COP). Then this chapter outlines the questions that raise the problems that will be expressed in this research, achieve the purpose of the research, the contribution expected to be achieved, the formation of construction and the overall structure of the research.

Acknowledgement

\section{References}

Moffitt, T. E. (2017). Adolescence-limited and life-course-persistent antisocial behavior: A developmental taxonomy. In Biosocial theories of crime (pp. 69-96). Routledge.

Silver, A. (2017). The demand for order in civil society: A review of some themes in the history of urban crime, police, and riot. In Theories and origins of the modern police (pp. 2346). Routledge. 
Becker, H. K. (2017). Community policing: the US experience. In Criminal Justice Research: Inspiration Influence and Ideation (pp. 159-187). Routledge.

Nitsch, H., \& Ronert, S. (2017). Community policing and radicalization: Evaluation and European examples. In Community Policing-A European Perspective (pp. 67-82). Springer, Cham.

Cross, C. (2015). Community policing and the politics of local development in Tanzania. Journal of Modern African Studies. Cambridge University Press. https://doi.org/10.1017/S0022278X14000433.

Pridmore, J., Mols, A., Wang, Y., \& Holleman, F. (2019). Keeping an eye on the neighbours: Police, citizens, and communication within mobile neighbourhood crime prevention groups. The Police Journal: Theory, Practice and Principles, 92(2), 97-120. https://doi.org/10.1177/0032258x18768397.

Ghani, Z. A. (2017). A comparative study of urban crime between Malaysia and Nigeria. Journal of Urban Management, 6(1), 19-29

Kanyo, N. I., Nor, N. H. M., Rainis, R., Rahman, A. T. A., \& Jubit, N. (2017). Mengurus ruang jenayah: Suatu tinjauan dasar pengurangan jenayah di Malaysia (Managing the crime space: A review of Malaysian crime reduction policies). Geografia-Malaysian Journal of Society and Space, 11(2).

Rasdi, Irniza \& Saliluddin, Suhainizam. (2018). ARE MALAYSIAN POLICE REALLY STRESSED? UNDERSTANDING THEIR POTENTIAL STRESS FACTORS. International Journal of Public Health and Clinical Sciences. 2. 45-53.

Makin, D. A., \& Marenin, O. (2017). Let's dance: Variations of partnerships in community policing. Policing: A Journal of Policy and Practice, 11(4), 421-436.

Leventakis, G., Kokkinis, G., \& Papalexandratos, G. (2017). Community policing case studies: Proposing a social media approach. In Community policing-a European perspective (pp. 139-156). Springer, Cham.

Rukus, J., Warner, M. E., \& Zhang, X. (2018). Community policing: Least effective where need is greatest. Crime \& Delinquency, 64(14), 1858-1881.

Mburu, L., \& Helbich, M. (2017). Communities as neighborhood guardians: A spatio-temporal analysis of community policing in Nairobi's suburbs. Applied Spatial Analysis and Policy, 10(2), 189-210.

Crowl, J. N. (2017). The effect of community policing on fear and crime reduction, police legitimacy and job satisfaction: an empirical review of the evidence. Police Practice and Research, 18(5), 449-462.

Ibrahim, B., Saleh, M., \& Mukhtar, J. I. (2016). An overview of Community Policing in Nigeria. In Conference paper.

Crawford, A., \& Evans, K. (2017). Crime prevention and community safety (pp. 797-824). Oxford University Press.

Makin, D. A., \& Marenin, O. (2017). Let's dance: Variations of partnerships in community policing. Policing: A Journal of Policy and Practice, 11(4), 421-436.

Zhao, Q., Jiang, T., Zhao, F., \& Ma, B. (2018, August). LCM: A Latent Communities Model based Community Detection Algorithm. In 2018 IEEE/CIC International Conference on Communications in China (ICCC) (pp. 74-78). IEEE.

Tsion, E. (2019). Feasibility Analysis of Long Short-Term Memory Recurrent Neural Network in Time Series Crime Prediction: A Case of Bole Sub City Police Department (Doctoral dissertation, ASTU). 